\title{
Covid-19 Sürecinde Havacılık Sektöründe Tüketici Davranışları (Consumer Behavior in Aviation Sector in Covid-19 Process)
}

\section{Tülay ÖZKAN (iD) a}

a Burdur Mehmet Akif Ersoy Üniversitesi, Sosyal Bilimler MYO, Burdur, Türkiye. tulayozkan@mehmetakif.edu.tr

\begin{tabular}{|c|c|}
\hline MAKALE BİLGİsí & ÖZET \\
\hline Anahtar Kelimeler: & ç - Bu çalışmanın amacı, tüketici davranışlarında duygusal motivatör olarak geçen korkunun ve \\
\hline $\begin{array}{l}\text { Hava yolu Taşımacılığı } \\
\text { Havacılık Sektörü }\end{array}$ & $\begin{array}{l}\text { oluşan beklentilerin Covid-19 sürecinde havacılık sektöründe tüketiciler/yolcular üzerindeki } \\
\text { etkilerini belirlemeye yöneliktir. }\end{array}$ \\
\hline Korku Pazarlaması & intem - Çalışma kapsamında Covid-19 pandemi sürecinde korkular, tutumlar ve beklentiler \\
\hline Beklenti & erine oluşturulan modelin araştırması iki aşamada gerçekleştirilmiştir. Birinci ç \\
\hline Tutum & $\begin{array}{l}\text { formu ve ikinci aşamada nitel soru ve nicel ifadelerin yer aldığı form katılımcılara çevrimiçi olarak } \\
\text { uygulanmıştır. Çalışmada elde edilen veriler, Eylül - Aralık } 2020 \text { tarihleri arasında } 18 \text { yaş üstü ve }\end{array}$ \\
\hline $\begin{array}{l}\text { Gönderilme Tarihi } 11 \text { Aralık } \\
2020\end{array}$ & $\begin{array}{l}\text { daha önce en az bir kez hava yolu ile seyahat etmiş gönüllü katılımcılardan elde edilmiştir. Birinci } \\
\text { aşamadaki nitel çalışmaya } 278 \text { kişi, ikinci aşamadaki karma çalışmaya } 356 \text { kişi katılmıştır. Verilere }\end{array}$ \\
\hline Revizyon Tarihi 7 Mart 2021 & ımlayıcı, güvenilirlik analizi, korelasyon, açımlayıcı ve doğrulayıcı faktör analizi ile yapısal \\
\hline Kabul Tarihi 20 Mart 2021 & delleme analizi yapılmıştır. \\
\hline $\begin{array}{l}\text { Makale Kategorisi: } \\
\text { Araştırma Makalesi }\end{array}$ & $\begin{array}{l}\text { Bulgular - Elde edilen sonuçlara göre, hava yolu taşımacılığını tercih edecek yolcuların Covid-19 } \\
\text { sürecinde oluşan korkularının beklentileri ve tutumları üzerinde pozitif etkileri olduğu tespit } \\
\text { edilmiştir. }\end{array}$ \\
\hline
\end{tabular}
Araştırma Makalesi

Tartışma - Tüketici davranışlarında duygusal motivatör olarak geçen korkular, Covid-19 süreciyle havacılık sektörü için oluşan beklentiler ve tutumlar arasındaki ilişki ampirik olarak incelerek sonuçlar tartışılmıştır.

\begin{tabular}{l} 
ARTICLE INFO \\
\hline Keywords: \\
Airline Transportation \\
Aviation Sector \\
Fear Marketing \\
Expectation \\
Attitude
\end{tabular}

Received 11 December 2020

Revised 7 March 2021

Accepted 20 March 2021

Article Classification: Research Article

\section{ABSTRACT}

Purpose - The present study aims to determine the effects of fear, which is an emotional motivator in consumer behavior, and expectations on consumers / passengers in the aviation industry during the Covid-19 process.

Design/methodology/Approach - Within the scope of the study, the research of the model built on fears, attitudes and expectations during the Covid-19 pandemic process was carried out in two stages. The qualitative questionnaire form in the first stage and the form containing qualitative questions and quantitative statements in the second stage were applied to the participants online. The data obtained in the study were obtained from volunteer participants over the age of 18 and who have traveled by air between September and December 2020 at least once. 278 people participated in the qualitative study in the first phase and 356 in the mixed study in the second phase. Descriptive, reliability analysis, correlation, exploratory and confirmatory factor analysis and structural modeling analysis were performed on the data.

Findings - According to the results, it has been determined that the fears of passengers who prefer air transportation during the Covid-19 process have positive effects on their expectations and attitudes.

Discussion - The relationship between fears, which are referred to as emotional motivators in consumer behavior, expectations and attitudes for the aviation industry with the Covid-19 process, were empirically examined and the results were discussed. 


\section{Giriş}

2019 yılı sonunda tüm dünyayı etkisi altına alan Çin'in Wuhan şehrinde baş gösteren Covid-19 salgını, küresel ticarete ilişkin ekonomik faaliyetleri azalttığı gibi hava taşımacılık operasyonlarının da gerilemesine neden olmuştur. Dünya Sağlık Örgütü önerileri doğrultusunda Covid-19'un bulaşıcılık etkisinden korunmak amacıyla ülkeler, öncelikli olarak hava taşımacılığı kısıtlamışlar ardından ise tamamen uçuşları durdurarak sınırlarını kapatmışlardır (Akça, 2020). Covid-19 pandemi süreci önlemlerinin 2020'nin mayıs ayından itibaren gevşetilmeye başlamasıyla hava yolu taşımacılığında da kısmi olarak canlanmanın olduğu gözlemlenmektedir. Bu çalışmanın konusu, tüketici davranışlarında duygusal motivatör olarak geçen ve Covid-19 sürecinde oluşan korkuların havacıllk sektörünü tercih eden yolcular üzerindeki etkisini araştırmaktır. Covid-19 pandemi sürecinde insanların üzerinde birtakım korkuların oluştuğu TV/internet haberlerinden, sosyal medyadan, insanların diyaloglarından anlaşılmaktadır (Depoux vd.,2020). Hijyen, sosyal mesafe, gıdaların güvenliği, sağlıklı yaşamak gibi önceden de önemli olan ancak Covid-19 sürecinde bu durumun farkına varan insanların sayısının arttığı düşünülünce satın alma davranışlarının da değişmesi kaçınılmazdır (De Meyer, 2020). Bu savdan yola çıkarak bu çalı̧̧mada, Covid-19 sürecinde tüketiciler üzerinde oluşan çeşitli korkuların oluşturduğu farkındalıklar ve bu farkındalıklar sonucunda hava yolu taşımacılığına tüketicilerin bakış açısı ve tercih sebeplerinde meydana gelen değişimlerin belirlenmesi ile korkuların ve beklentilerin hava yolu taşımacıllğına etkisi ölçülecektir.

Covid-19 sürecinde hava yolu taşımacılığı ve tüketici davranışları üzerine yapılan çalışmalar incelendiğinde Graham vd., (2020)'nin 65 yaş ve üstü hava yolu yolcularının pandemi sürecinden beri tutumlarını inceledikleri çalışmalarında önümüzdeki (2021 yılı için) 12 ay içerisinde hava yoluyla seyahat etmek istediklerini ancak esnek bilet rezervasyonu, karantina kurallarına uyulması, self servis teknolojilerin kullanımı gibi faktörlerin gerçekleşmesi halinde hava yolunu en güvenli seyahat olarak görülmektedir. Beck ve Hensher (2020)'un çalışmasında araştırmaya katılan yolcuların sadece \%2'si uçukla seyahat yapmayı planlamaktadır, çoğunluğu uçuş planlarını iptal etmiş veya rezervasyonlarını askıya almıştır. De Haas vd. (2020) de benzer bir şekilde 65 yaşın altındaki insanların \%16'sından azı hava yolculuğunu azaltmayı beklerken, 65 yaş ve üstü insanların \%43'ünün azaltmaları beklenmektedir. Ivanova vd. (2020) sosyal medya üzerinden yaptığı çevrimiçi anket çalışmasında, katılımcılar seyahat etmek istediklerinde tercih ettikleri taşıma türü öncelikli olarak büyük oranda kendi arabaları, ikinci sırada hava taşımacıllğı, üçüncü sırada tren ve dördüncü sırada ise tur otobüsü oluşturmaktadır. Bu bağlamda Covid-19 sürecinde havacılık sektöründe tüketici davranışları üzerine sınırlı sayıda çalışmaya Grahan vd. 2020; Beck ve Hensher, 2020; De Haas vd., 2020; Inanova vd., 2020) rastlanılmıştır. Bu çalışma, Covid-19 sürecinde oluşacak korkuları ve bu korkuların havacılık sektörünü kullanan/kullanacak yolcuların davranışlarına etkisini genel olarak inceleyecek olmasından dolayı diğer çalışmalardan ayrılmaktadır. Araştırmanın insanların bu gibi durumlarda sürü psikolojisine kapılarak korkunun yayılmasının hava yolu taşımacılığından beklentiler ve tercih davranışlarına yansımasını betimleyecek ve ölçecek olmasından dolayı literatüre önemli bir katkı sağlayacağı düşünülmektedir.

\section{Kavramsal Çerçeve}

\subsection{Korku Pazarlaması, Beklentiler ve Tutumlar}

Pazarlamada korku kavramı Papatya (2010)'a göre: “işletmelerin olan/olası pazar paylarını artırmaya yönelik insan psikolojisini kontrol altında tutarak tüketim kültürü/ağlarını yönetmede ve psikolojik savaş yöntemlerini uygulamada en yaygın kullanım olanağı bulan pazarlama işlev ve süreçlerinden biri" olarak ele alınmakla birlikte korku pazarlaması, sağlıkta, siyasette, eğitimde, bilimde, sanatta, savaşta, ilişkilerde, kısacası tüketim ideolojisiyle toplumların tüketildiği hayatın tüm alanlarında kullanılan endüstriyel bir araç haline dönüşmüştür. Özer ve Aksoy (2018)'e göre bu durum insanların belirli bir olgu karşısında tedirgin hale getirilip pazarlanması amaçlanan ürüne/hizmete karşı korku oluşturulan olguya çözüm olarak yönlendirilmesi ise "korku çekiciliği” kavramı ile açıklanmaktadır (Özkan, 2020).

Korku pazarlaması üzerine literatür incelendiğinde kavram olarak daha çok "korku çekiciliği" (Balcı, 2006; Çakar, 2009; Gürdin, 2016; Seki, 2017; Çakı, 2018; Erol, 2017; Özer ve Aksoy, 2018), “bir pazarlama aracı olarak korku" (Fırat, 2013; Avcı, 2017; Derendeli, 2019; Kılıç ve Derendeli, 2020), "korkunun tüketici davranışları üzerindeki etkisi" (Çevik, 2011; Akyüz vd., 2017; Yiğit, 2018; Sarıyer, 2019; Firat ve Yıldız, 2019) olarak ele alınmaktadır. Son olarak kapsamlı bir şekilde teorik boyutta “korku pazarlaması"nı Papatya (2010)'nın 
seminal makalesinde ve Korkmaz ve Dal (2020) çalışmalarında ele aldıkları görülmektedir. Yapılan bu araştırmalarda ele alınan korku üzerine temel konuların ise, gıda, savaş, güvenlik, sağlık, dini yasaklar vd. olgular üzerine olduğu anlaşılmaktadır.

Literatürden anlaşılacağı üzere birçok sektörde (gıda, sağlık, güvenlik vs..) oluşan/oluşturulan korkuların (korku motivatörünün) tüketici beklenti ve tutumlarını etkilediği varsayılmaktadır (Avcı, 2017; Seki, 2017; Fırat, 2013; Çevik, 2011; Akyüz vd., 2017; Yiğit, 2018; Sarıyer, 2019; Fırat ve Yıldız, 2019; Min vd., 2012). Bu bağlamda beklentiler, müşteriler daha hizmeti almadan önce oluşmakta, hizmete/ürüne ilişkin istek ya da arzuları ifade etmektedir (Parasuraman vd., 1985; Savaş ve Kesmez, 2014). Müşteri memnuniyeti, müşterinin beklentileri ile gerçekleşen performans arasındaki tutarsızlıklardan kaynaklandığına göre müşteri beklentileri, tutumun belirleyicisi olmaktadır (Hsu vd., 2010; Ro ve Ha, 2017).

Tutum kavramı ise Fishbein ve Ajzen (1975) tarafından "belirli bir nesneye göre sürekli olarak olumlu veya olumsuz bir şekilde yanıt vermeye yönelik öğrenilmiş bir yatkınlık" olarak tanımlanmaktadır. Planlı Davranış Teorisi (PDT)'ni geliştiren yazarlara göre, bir tutumu uyandırmak veya geliştirmek için gerekli koşulların belirlenebildiğini ve bu tür koşulların tutumun motivasyonel temeline göre değişeceğini varsaymaktadır. Bununla birlikte, teorileri, motivasyonun tutumdan önce geldiğini ve ilkinin ikincisini etkileyebileceğini ileri sürmektedir (Hsu vd., 2010; Şentürk, 2020). Örneğin reklamların oluşturduğu korkular, pazarlamada duygusal motivatör olarak geçmektedir ve tüketicilerin duygularına seslenerek davranıslarına etki etmektedir. Böylelikle duygusal yönlü öğelerle tutum oluşturulmaktadır (Babür Tosun, 2010).

Sonuç bağlamında Min vd. (2012)'nin motivasyonun (korku motivasyonu) beklentileri etkilediği; Hsu vd., (2010), Ro ve Ha, (2017)'nin beklentilerin tutumu etkilediği ve Hsu vd. (2010)'nin PDT kuramindan yola çıkarak motivasyonun (korku motivasyonu) tutumu pozitif yönde etkilediği hipotezleri benimsenmiş ve aşağıdaki hipotezler geliştirilmiştir:

H1: Covid-19 sürecinde korkuların oluşturduğu farkındalıkların hava yolu taşımacılığını kullanacak olan yolcuların beklentileri üzerindeki etkisi pozitiftir.

$\mathbf{H}_{2}$ : Covid-19 sürecinde oluşan beklentilerin hava yolu taşımacılığını kullanacak olan yolcuların tutumları üzerindeki etkisi pozitiftir.

H3: Covid-19 sürecinde korkuların oluşturduğu farkındalıkların hava yolu taşımacılığını kullanacak olan yolcuların tutumları üzerindeki etkisi pozitiftir.

\section{Yöntem}

\subsection{Araştırmanın Amacı}

Araştırmanın ana amacı, tüketici davranışlarında duygusal motivatör olarak geçen korkunun covid-19 sürecinde havacılık sektöründe tüketiciler/yolcular üzerindeki etkisini ortaya çıarmaktır. Bu amaç doğrultusunda ölçek geliştirmeye çalışılmıştır.

$\mathrm{Bu}$ araştırma için, Burdur Mehmet Akif Ersoy Üniversitesi Girişimsel Olmayan Klinik Araştırmalar Etik Kurulu, 20.08.2020 tarih, GO 2020/196 sayılı etik kurul raporu alınmıştır. Katılımcılardan veriler toplanmadan önce elektronik ortamda bilgilendirilmiş onam alınmıştır.

Araştırma soruları ise aşağıdaki gibidir;

- Covid-19 süreciyle birlikte insanlar hangi şartlarda hava yolu taşımacılığını kullanır?

- Covid-19 süreciyle oluşan korku ve beklentilerin hava yolu taşımacılığını tercih edecek yolcuların tutumları üzerindeki etkileri nelerdir? şeklindedir.

\subsection{Araştırmanın Aşamaları}

Birinci Aşama: Çalışmanın ilk aşamasında ölçek ifadelerinin belirlenmesi için keşifsel bir araştırma yapılmıştır. 18 yaş üstü, daha önce hava yolu ile seyahat etmiş, farklı sektörlerde çalışan ve rastgele ulaşılan 278 kişiye açı uçlu olarak "Covid-19 sürecinde bir tüketici olarak havacılık sektöründe ne tür önlemlerin alınması sonucunda hava yolu taşımacılığını kullanmayı düşünürdünüz?" şeklinde bir soru yöneltilmiştir. Birinci araştırma, Eylül 2020 ayı içerisinde Google formu aracılığı ile çevrimiçi olarak yapılmıştır. İkinci araştırmaya birinci aşama bittikten sonra Eylül ayı sonunda başlanmıştır. 
Elde edilen ifadeler ayrıntılı bir şekilde incelenmiştir. Verilen cevaplardan benzer özellikler taşıyan ifadeler bir araya getirilmiş, tekrarlanan ve ilgisiz olan ifadeler ise kapsam dışı bırakılmıştır. Değerlendirmeler sonucunda beklentiler 12 ve tutumlar için 4 toplamda 16 ifadeye ulaşılmıştır. Bu ifadeler literatürdeki Covid19 sürecinde yapılan çalışmalarla örtüşecek şekilde yeniden düzenlenmiştir (Eroğlu, 2020; Akça, 2020; Macit ve Macit, 2020; Cotfas vd., 2020; http-1, http-2, http-3). Araştırma konusu üzerine Covid sürecinde yapılan çalışmalarda herhangi bir ölçeğe rastlanmamıştır. Oluşturulan ölçeğin maddeleri kapsam geçerliliği için alanında uzman olan kişilere danışılarak alınan görüş ve öneriler doğrultusunda yeniden revize edilmiştir.

Arastaman vd., (2018)'ne göre nitel araştırma yöntemlerinin doğası, istatistiksel veya ampirik hesaplamalara dayanmamasından dolayı nitel araştırmalarda geçerlik ve güvenirlik konusu okuyucuları ikna etme çabası olan güven duyulabilirlik ile ilişkilendirilmektedir. Nitel bir araştırmanın güven duyulabilirliğini; inandırıcılık, aktarılabilirlik, güvenilebilirlik ve onaylanabilirlik ölçütleri sağlamaktadır. Bu noktada yukarıdaki açıklamalar doğrultusunda araç geliştirme amacı güden bu araştırmanın güven duyulabilirliğinin sağlandığı varsayılmaktadır. Bunlar;

- İnandırıcılık: Katılımcıların rastgele seçilmesine dikkat edilmiştir ve ikinci olarak meslektaş değerlendirmesine başvurulmuş ve gerekli revize işlemleri gerçekleştirilmiştir.

- Aktarılabilirlik: Katılımcılarla ilgili sınırlılıklar, katılımcı sayısı, veri toplama yöntemi ve süresi gibi bilgiler verilmiştir.

- Güvenilebilirlik: Araştırma etkinlikleri ve süreçleri ayrıntılı bir şekilde verilmiştir.

- Onaylanabilirlik: Araştırma bulguları, araştırmacının özellikleri ve seçimlerinden değil de katılımcıların deneyim ve düşüncelerinden kaynaklanmaktadır.

İkinci Aşama: Çalışmanın bu aşamasında çevrimiçi hazırlanan anket formu iki bölümden oluşmaktadır. Birinci bölümde katılımcıları tanımlayıcı sorular yer almaktadır. İkinci bölümde ise 21 kapalı ifade ve 1 açık uçlu soru bulunmaktadır.

Açık uçlu soru: "Covid-19 sürecinde bir tüketici olarak havacılık sektöründe ne tür önlemlerin alınması sonucunda hava yolu taşımacılığını kullanmayı düşünürdünüz?" şeklindedir. Bu soru, araştırmada oluşturulan ölçeği ikinci kez desteklemek amaciyla oluşturulmuştur.

Kapalı uçlu sorulardan biri: “Hava yolu taşımacılı̆̆ında sizin için en önemli olan şey nedir?” çoktan seçmeli olarak hazırlandı ve içlerinden 3 tane seçim yapmaları istenmiştir. Seçim yapılacak maddeler ise APEX Yolcu Seçimi Ödüllerinin verilmesinde kategorilendirilen bilet fiyatının uygunluğu, kabin hizmetlerinin kalitesi, koltuk konforu, yiyecek/içecek kalitesine sağlık/hijyen tedbirlerinin alınması ilave edilerek genişletilmiştir.

Bunların dışında, birinci aşamada tespit edilen beklentiler ve tutumlara yönelik 16 ifade ve Özkan (2020)'ın Covid 19 Sürecinde Tüketici Davranışları adlı çalışmasından korkuların oluşturduğu farkındalıklar için 4 ifadeden yararlanılarak geliştirilen "kesinlikle katılıyorum (5 puan) ve kesinlikle katılmıyorum (1 puan)" arasında oluşan 5'li Likert tipi ölçek, 18 yaş üstü ve daha önce hava yolu ile seyahat etmiş gönüllü katılımcılara uygulanmıştır. Kurtuluş (2006)'ya göre 500.000 üzerindeki evren büyüklüğü için \%95 güven aralığında 322 katılımcı yeterli olmaktadır. Araştırmada çalışmaya 356 kişi katılım göstererek minimum düzeyin üzerinde katılımcı sağlanmıştır. Kass ve Tinsley (1979) ölçek geliştirme çalışmalarında toplamda en az 300 bireye ulaşılması ya da ölçekte yer alan madde sayısının en az beş veya on katı olması gerektiğini söylemektedir (Seçer, 2015). Araştırmada geliştirilen ölçekte 20 ifade bulunmaktadır ve 10 katından daha fazla katılımcı sayısına ulaşılmıştır.

Araştırmada, hava yolu ile en az bir kere seyahat eden yolculara ulaşılması gerektiği ve Covid-19 pandemi sürecinde olunmasından dolayı örnekleme yöntemi olarak tesadüfi olmayan örnekleme yöntemlerinden kolayda örnekleme yöntemi seçilmiştir (Gerçek, 2018; İslamoğlu ve Börü, 2007; Çalışkan, 2020). Katılımcıların $\% 53$ 'ü kadın, \%55,6's evli değil, \%92'si üniversite mezunudur. Yaş dağılımları ise \%45'i 18-30 yaş arası, \%31'i 31-40 yaş arası, \%14'ü 41-50 yaş aralığındadır. Araştırma verileri Eylül - Aralık 2020 ayları arasında çevrimiçi olarak toplanmıştır. 


\subsection{Analiz Yöntemleri}

Betimleyici analizlerin yanı sıra nicel ifadelerin analizine başlamadan önce gerekli ön testler yapıldıktan sonra araştırma ölçeğinin yapı geçerliliği için Açımlayıcı Faktör Analizi uygulanmıştır. Bu analizden sonra güvenilirlik için Cronbach Alpha katsayıları hesaplanmıştır. Alpha değerinin 0.70'den yüksek olduğu görülmüştür. Elde edilen bulgulara göre ölçeğin güvenilir bir ölçme aracı olduğu sonucuna varılmıştır (Büyüköztürk, 2009). Bu aşamadan sonra korkuların oluşturduğu farkındalıklar, beklentiler ve tutumlar arasındaki ilişkiyi belirlemek amacıyla Pearson Korelasyon Analizi yapılmış ve aritmetik ortalama ile standart sapma değerleri bulunmuştur.

Açımlayıcı Faktör Analizi ile ortaya konulan yapının doğrulanması için Doğrulayıcı Faktör Analizi (DFA) uygulanmıştır. DFA ise belirlenen faktörler arasında yeterli düzeyde ilişkinin olup olmadığını, hangi değişkenlerin hangi faktörlerle ilişkili olduğunu, faktörlerin birbirinden bağımsız olup olmadığını, faktörlerin modeli açıklamakta yeterli olup olmadığını test etmek amacıyla kullanılmaktadır (Büyüköztürk, 2009; Seçer, 2015; Karakoç ve Dönmez, 2014).

\subsection{Geçerlilik ve Güvenirlik Analizleri}

Açımlayıcı faktör analizinde öncelikle Kaise-Meyer-Olkin (KMO) ve Barlett'in küresellik testi sonuçlarına bakılması gerekmektedir. KMO değerinin $0.5^{\prime}$ ten büyük olması ve 1'e yakın olması örneklem büyüklügünün yeterliliği hakkında bilgi vermektedir. .887>0.5 olduğu için veri setimizin faktör analizine uyun olduğunu söyleyebiliriz. Barlett'in küresellik testine ilişkin p değerinin de $0.05^{\prime}$ den küçük olması gerekmektedir (Kalaycı, 2008; Seçer, 2015). Veri setimizin p değeri .000 olduğu için Barlett testi anlamlıdır ve değişkenler arasında yüksek korelasyonlar mevcuttur. Veri setinin faktör analizine uygun olduğunu gösteren Barlett ve KMO testi sonuçları Tablo 1'de verilmiştir.

Tablo 1: KMO ve Barlett Küresellik Testleri Sonuçları

\begin{tabular}{|l|l|}
\hline KMO Örneklem Yeterliliği Ölçümü & .887 \\
\hline Bartlett'in Küresellik Testi Ki Kare (p) & $4.775,198(.000)$ \\
\hline Serbestlik & 190 \\
\hline
\end{tabular}

Analizde her bir faktörün öz değerinin (eigen value) 1'den büyük olması (Tablo 2) ve madde yük değerlerinin alt sınır olarak kabul edilen 0.30 'dan büyük olması anlamlılık ifade etmektedir (Kalaycı, 2008). Faktör yük değeri alt sınırın altında kalan ya da birden fazla faktörde yer alan maddeler (B2 ve T2) ölçekten çıkarılmıştır (Tablo 3).

Tablo 2: Açıklanan Toplam Varyans Miktarları

\begin{tabular}{|c|c|c|c|c|c|c|}
\hline \multirow{2}{*}{ Faktör } & \multicolumn{3}{|c|}{ Başlangı Ö Özdeğerleri } & \multicolumn{3}{c|}{ Faktör Yüklerinin Döndürülmüş Toplamları } \\
\cline { 2 - 7 } & Toplam & Varyans \% & Kümülatif \% & Toplam & Varyans \% & Kümülatif \% \\
\hline 1 & 8,255 & 45,864 & 45,864 & 6,676 & 37,088 & 37,088 \\
\hline 2 & 2,181 & 12,119 & 57,982 & 3,306 & 18,368 & 55,456 \\
\hline 3 & 1,603 & 8,906 & 66,888 & 2,058 & 11,433 & 66,888 \\
\hline
\end{tabular}

Faktör analizi sonucunda Korkular faktörü 4 boyuttan oluşmaktadır ve ölçeğin toplam varyansının \%45.86'sını açıklamaktadır. Beklentiler faktörü 11 boyuttan oluşmaktadır ve ölçeğin toplam varyansının \%12.12'sini açıklamaktadır. Son olarak Tutumlar faktörü 3 boyuttan oluşmaktadır ve ölçeğin toplam varyansının \%8,9'unu açıklamaktadır. Faktör analizi sonucunda ölçek toplam varyansın 66.89'unu açıklamaktadır. Bu değer de \%50'yi geçiyor olması faktör analizi için önemli bir kriterdir (Büyüköztürk, 2009). 
Tablo 3: Faktör Analizi Sonrası Döndürülmüş Madde Bileşenleri Sonuçları

\begin{tabular}{|c|c|c|c|c|}
\hline & & Yükler & $\begin{array}{l}\text { Varyansın } \\
\text { Açıklanma } \\
\text { \%'si }\end{array}$ & $\begin{array}{l}\text { Cronbach } \\
\text { Alpha }\end{array}$ \\
\hline \multicolumn{5}{|c|}{ Korkuların Oluşturduğu Farkındalıklar } \\
\hline K1 & $\begin{array}{l}\text { Covid süreciyle bağışıklık sisteminin güçlendirilmesinin ne } \\
\text { kadar önemli olduğunu herkes fark etmiştir. }\end{array}$ & .862 & & \\
\hline $\mathrm{K} 2$ & $\begin{array}{l}\text { Covid süreciyle sağlıklı/doğal beslenmenin önemi ortaya } \\
\text { çımıştır. }\end{array}$ & .821 & 37.09 & .90 \\
\hline K3 & Covid süreciyle sağlıklı yaşamanın önemi ortaya çıkmıştır. & .815 & & \\
\hline K4 & $\begin{array}{l}\text { Covid süreciyle hijyene dikkat etmenin ne kadar önemli } \\
\text { olduğunu herkes fark etmiştir. }\end{array}$ & .846 & & \\
\hline \multicolumn{5}{|c|}{ Beklentiler } \\
\hline B1 & $\begin{array}{l}\text { Uçakta sosyal mesafeye uygun boş koltuk uygulaması } \\
\text { yapılmalıdır. }\end{array}$ & .598 & & \\
\hline B2 & $\begin{array}{l}\text { Uçakta verilen hizmet kapsamında yiyecek ve içecek } \\
\text { servislerinin durdurulması gerekir. }\end{array}$ & - & & \\
\hline B3 & $\begin{array}{l}\text { Havaalanlarında tuvalet ve lavaboların temizliğine daha fazla } \\
\text { dikkat edilmesi gerekir. }\end{array}$ & .764 & & \\
\hline B4 & $\begin{array}{l}\text { Yoğun istasyonlarda check-in işlemleri sırasında oluşacak } \\
\text { kuyrukları minimize edecek tedbirlerin alınması gerekir. }\end{array}$ & .782 & & \\
\hline B5 & $\begin{array}{l}\text { Hava yolu taşımacılı̆̆ında yolculara ücretsiz maske, mini çöp } \\
\text { torbası, kâğıt mendil gibi hijyen maddelerinin verilmesi gerekir. }\end{array}$ & .710 & & \\
\hline B6 & $\begin{array}{l}\text { Yolcuların sosyal mesafeye dikkat etmesine yönelik çalışanlar } \\
\text { tarafından uyarıların sürekli yapılması gerekir. }\end{array}$ & .845 & 18.37 & .93 \\
\hline B7 & Havalimanı ve uçaklar dezenfekte edilmelidir. & .802 & & \\
\hline B8 & Termal kameralar artırılmalı ve takip edilmelidir. & .821 & & \\
\hline B9 & $\begin{array}{l}\text { Havalimanı girişinde ateş ölçümü yapılması ve maskesiz } \\
\text { kimsenin alınmaması gerekir. }\end{array}$ & .808 & & \\
\hline B10 & $\begin{array}{l}\text { Uçakta iki koltuk arasındaki birleşim yerlerinde şeffaf koruma } \\
\text { bariyerleri koyulabilir. }\end{array}$ & 687 & & \\
\hline B11 & $\begin{array}{l}\text { Uçak ve yer hizmetlerindeki tüm çalışanlar maske ve eldiven } \\
\text { kullanmalıdır. }\end{array}$ & .774 & & \\
\hline B12 & $\begin{array}{l}\text { Havalimanında ve uçakta tüm süreçlerde dezenfektan } \\
\text { kullanımına dikkat edilmelidir. }\end{array}$ & .764 & & \\
\hline \multicolumn{5}{|c|}{ Tutumlar } \\
\hline $\mathrm{T} 1$ & $\begin{array}{l}\text { Covid süreciyle taşıma fiyatlarının yükselmesi halinde en } \\
\text { sağlıklı-hijyen taşıma sistemi hangisi ise fiyatına bakmadan } \\
\text { onunla ulaşımımı sağlarım. }\end{array}$ & .592 & & \\
\hline $\mathrm{T} 2$ & $\begin{array}{l}\text { Covid süreciyle taşıma fiyatlarının yükselmesi halinde bireysel } \\
\text { tedbirlerimi alarak en uygun fiyatlı taşıma sistemini tercih } \\
\text { ederim. }\end{array}$ & - & 11.43 & .88 \\
\hline T3 & $\begin{array}{l}\text { Hava yolu taşımacılığını diğer taşıma türlerine göre daha sağlıklı } \\
\text { buluyorum }\end{array}$ & .831 & & \\
\hline $\mathrm{T} 4$ & Hava yolu taşımacılığını diğer taşıma türlerine tercih ederim. & .857 & & \\
\hline
\end{tabular}

İkinci adımda ölçekte yer alan maddelerin faktör dağılımlarını belirlemek amacıyla faktörler arasında ilişkinin bulunduğu durumlarda kullanılan Direct Oblimin Dönüşüm Analizi yapılmıştır (Seçer, 2015; Kalaycı, 2008). İki maddenin ölçekten çıkarılmış son haliyle verilere yeniden faktör analizi yapılmıştır. Tablo 3'te ölçekte yer alan tüm maddelerin 0.30 'un üzerinde olduğu görülmektedir. En düşük değer 592 ve en yüksek değer ise .862 ' dir. Bu da her maddenin değerinin yüksek ve birbirleriyle ilişkili olduğu anlamına gelmektedir.

Analiz sonucunda Cronbach Alfa değerinin tüm boyutlarda 0.70 'den yüksek olduğu görülmüştür (Büyüköztürk, 2009). Bundan dolayı ölçeğin iç tutarlılığının güvenilir olduğu kabul edilmiştir (Tablo 3). 
Bunun dışında iki yarı güvenilirlik düzeyi de .809 olarak bulunmuştur (Spearman-Broqn korelasyon değeri .809; Guttman Split-Half değeri .809; Part 1 Alfa Değeri .882; Part 2 Alfa Değeri .804).

Veri setinin faktör analizi için uygun olup olmadığının değerlendirilmesinde korelasyon matrisine de bakılabilmektedir. Değişkenler arasında korelasyon katsayıları 0.30 ve üzerinde ise, bu değişkenlerin yüksek olasılıkla faktörler oluşturabileceklerini gösterir (Kalaycl, 2008). Tablo 4'te tüm değişkenler arasında korelasyon katsayılarının 0.30 'dan büyük olduğu anlaşılmaktadır.

Tablo 4: Değişkenler arası korelasyonlar

\begin{tabular}{lccc}
\hline Değişkenler & $\mathbf{1}$ & $\mathbf{2}$ & $\mathbf{3}$ \\
\hline Korkular & 1 & & \\
\hline Beklentiler & $.486^{* *}$ & 1 & 1 \\
\hline Tutumlar & $.317^{* *}$ & $.318^{* *}$ & 4.02 \\
\hline Ortalama & 4.40 & 4.81 & .900 \\
\hline Standart Sapma & .631 & .353 & \\
\hline
\end{tabular}

** Korelasyon 0.01 seviyesinde anlamlıdır.

\subsection{Doğrulayıcı Faktör Analizi}

DFA'da elde bulunan verinin daha önce kurgulanmış olan faktör yapısı ile uyumlu olup olmadığı test edilmektedir. Modelde uyum indeks değerleri kabul edilebilir seviyede çıkan model doğrultusunda ölçeğin faktör yapısı belirlenmektedir (Seçer, 2015). Tablo 5'te ölçüm setinin kabul edilebilir uyum indeksleri olduğu görülmektedir. Bunun dişında modifikasyon değerleri yüksek olan ve aynı faktörde yer alan bazı maddeler arasında kovaryanslar oluşturularak iyileştirmeler yapılmıştır (Khine, 2013).

Tablo 5: Doğrulayıcı Faktör Analizi Bulguları

\begin{tabular}{|l|c|c|c|c|c|c|c|c|c|}
\hline \multicolumn{1}{|c|}{$\begin{array}{c}\text { DFA } \\
\text { Modeli }\end{array}$} & $\mathbf{X}^{2}$ & df & $\mathbf{X}^{2} / \mathbf{d f}$ & RMSEA & NNFI & CFI & GFI & AGFI & $\begin{array}{c}\text { Cronbach } \\
\text { Alfa }\end{array}$ \\
\hline $\begin{array}{l}\text { Ölçüm } \\
\text { Seti }\end{array}$ & 357.35 & 117 & 3 & 0.076 & 0.97 & 0.97 & 0.90 & 0.85 & 0.90 \\
\hline $\begin{array}{l}\text { Kabul edilebilir } \\
\text { Uyum İndeksleri* }\end{array}$ & - & - & $5>\mathrm{x}>2$ & $<0.08$ & $>0.90$ & $>0.90$ & $>0.90$ & $>0.85$ & $\begin{array}{c}\text { Oldukça } \\
\text { güvenilir }\end{array}$ \\
\hline
\end{tabular}

*Kaynak: Schumacker ve Lomax, 2010; Schermelleh-Engel ve Moosbrugger, 2003:52; Seçer, 2015.

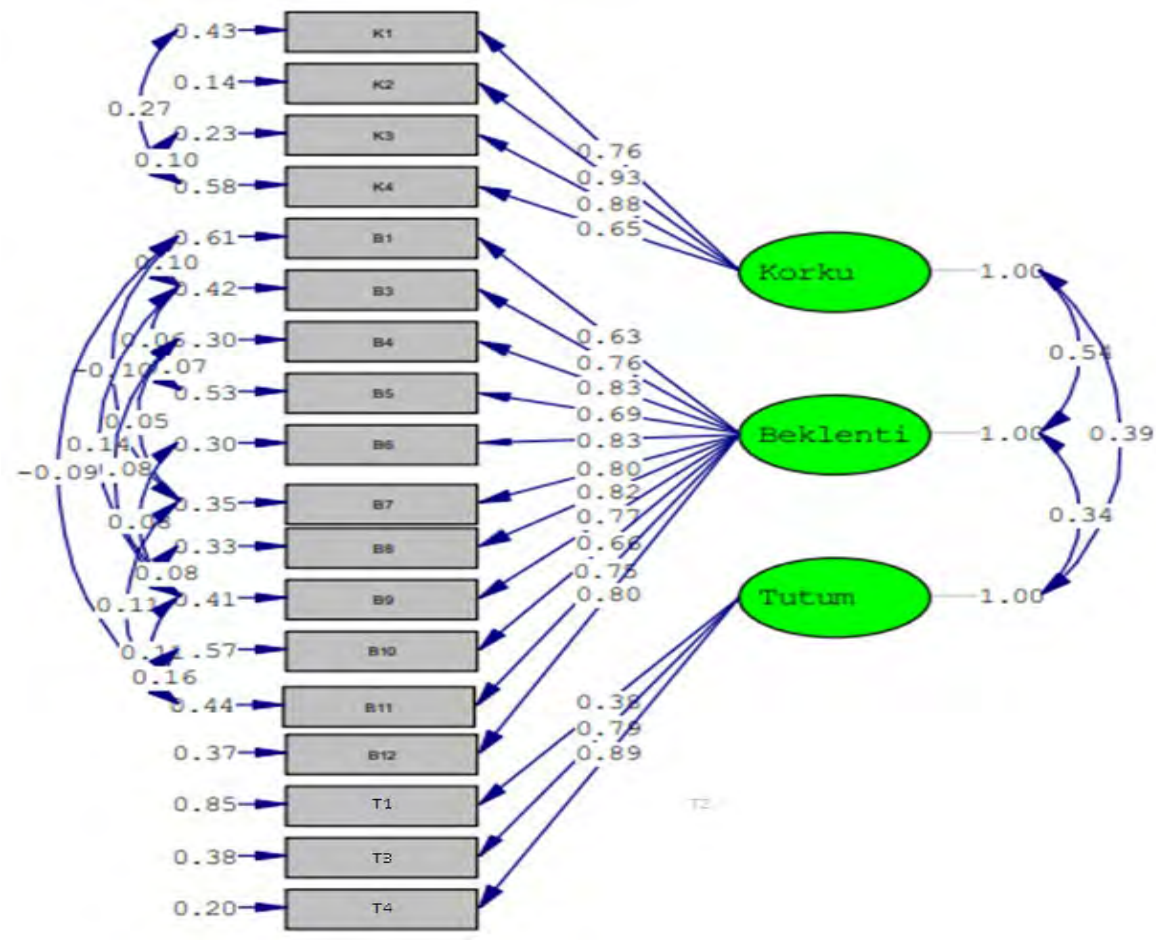

Şekil 1: DFA Sonuçları 


\subsection{Yapisal Model}

Araştırmanın ilk aşamasında güvenilirlik ve geçerlilik analizleri yapıldıktan sonra ikinci aşamada yapısal modelin değerlendirilmesine geçilmiştir.

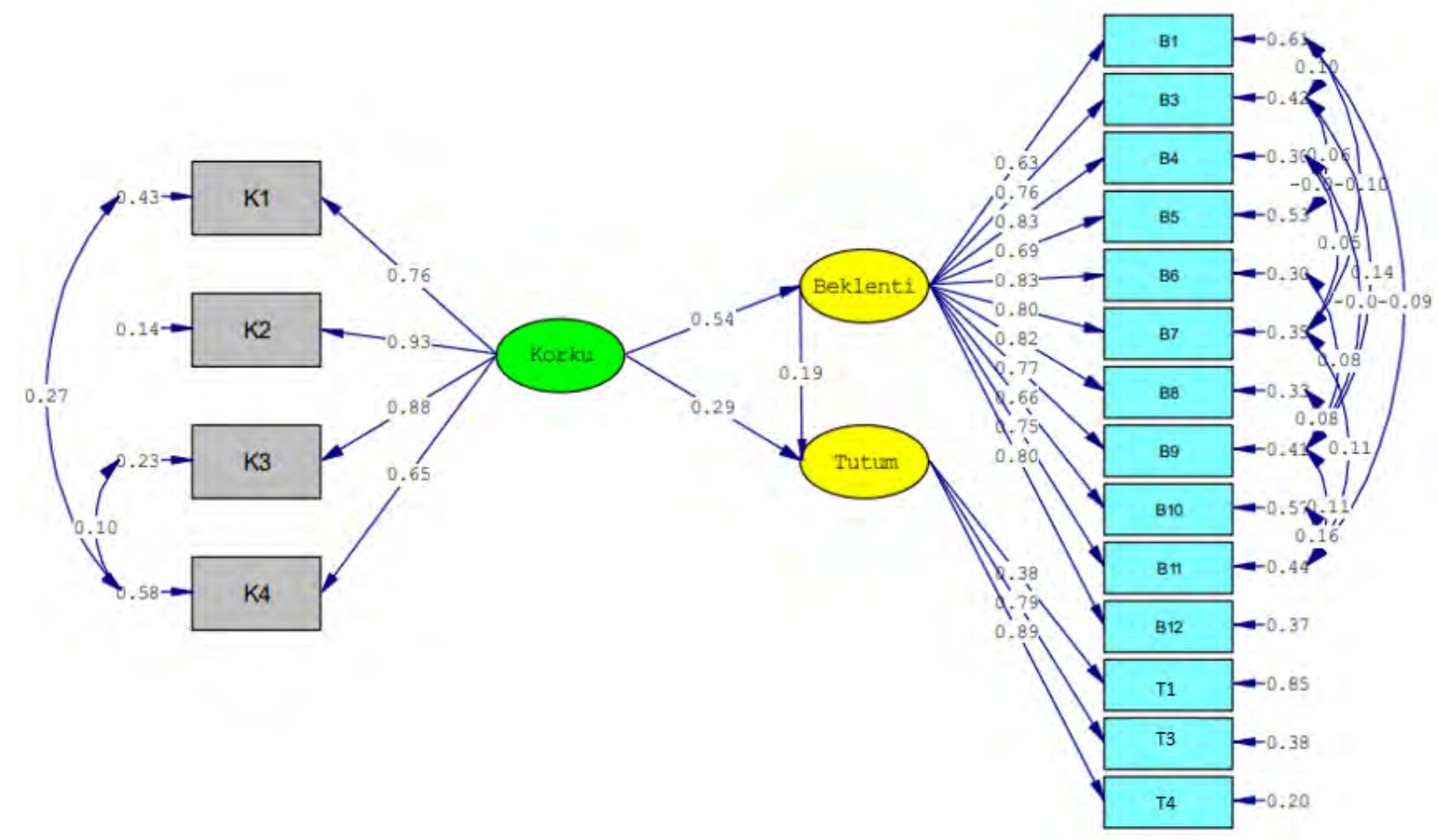

Şekil 2: Yapısal Model

Modelin uyum indekslerinin kabul edilebilir düzeylerde olması (Tablo-5) sonucunda hipotezleri test etmek için yol katsayılarına bakılmıştır (Tablo-6). t-değerlerinin \%95 güven aralığında 1.96, \%99 güven aralığında ise 2.58' den büyük olması gerekir (Schumacke ve Lomax, 2010). Harrington (2009)'a göre standardize edilmiş faktör yüklerinden 0.30 'un üstünde olan maddeler (gözlenen değişken) değerlendirmeye alınmaktadır (Çapık, 2014: 203). Şekil 1-2' de faktör yüklerinin 0.30 'un üstünde olduğu görülmektedir.

Tablo 6' da ise t değerlerinin 1.96 ' dan büyük olduğu anlaşılmakta ve böylelikle $\mathrm{H}_{1}, \mathrm{H}_{2}$ ve $\mathrm{H}_{3}$ hipotezleri kabul edilmektedir.

Tablo 6: Hipotez testi bulguları

\begin{tabular}{|c|c|c|}
\hline Hipotezler /İlişkiler & t-değeri & Kabul/Red \\
\hline $\mathrm{H}_{1} \quad$ Korkular $\quad->$ Beklentiler & 9.12 & Kabul \\
\hline $\mathrm{H}_{2}$ Beklentiler $->$ Tutumlar & 2.72 & Kabul \\
\hline $\mathrm{H}_{3} \quad$ Korkular $\quad \rightarrow$ Tutumlar & 4.04 & Kabul \\
\hline
\end{tabular}

\subsection{Hava yolu Taşımacılığı Hizmetlerinde Önemli Olan Unsurların Tespiti}

Grafik 1'de daha önce en az bir kere hava yolu taşımacılığını kullanan yolculara, hava yolu ile ulaşımda en önemli olan unsur/lar sorusu yöneltilmiştir. Bu soruya 179 katılımcı sağlık ve hijyen tedbirlerinin alınması, 126 katılımcı bilet fiyatının uygunluğu, 47 katılımcı koltuk konforu, 23 katılımcı kabin hizmetlerinin kalitesi ve son olarak 11 katılımcı yiyecek/içecek yani ikram hizmetlerinin kalitesini önemli olarak belirtmiştir.

Bu bulgular sonucunda yolcuların sağlık ve hijyenle ilgili tedbirlerin alınması ile bilet fiyatının uygunluğuna daha fazla önem verdikleri anlaşılmaktadır. 


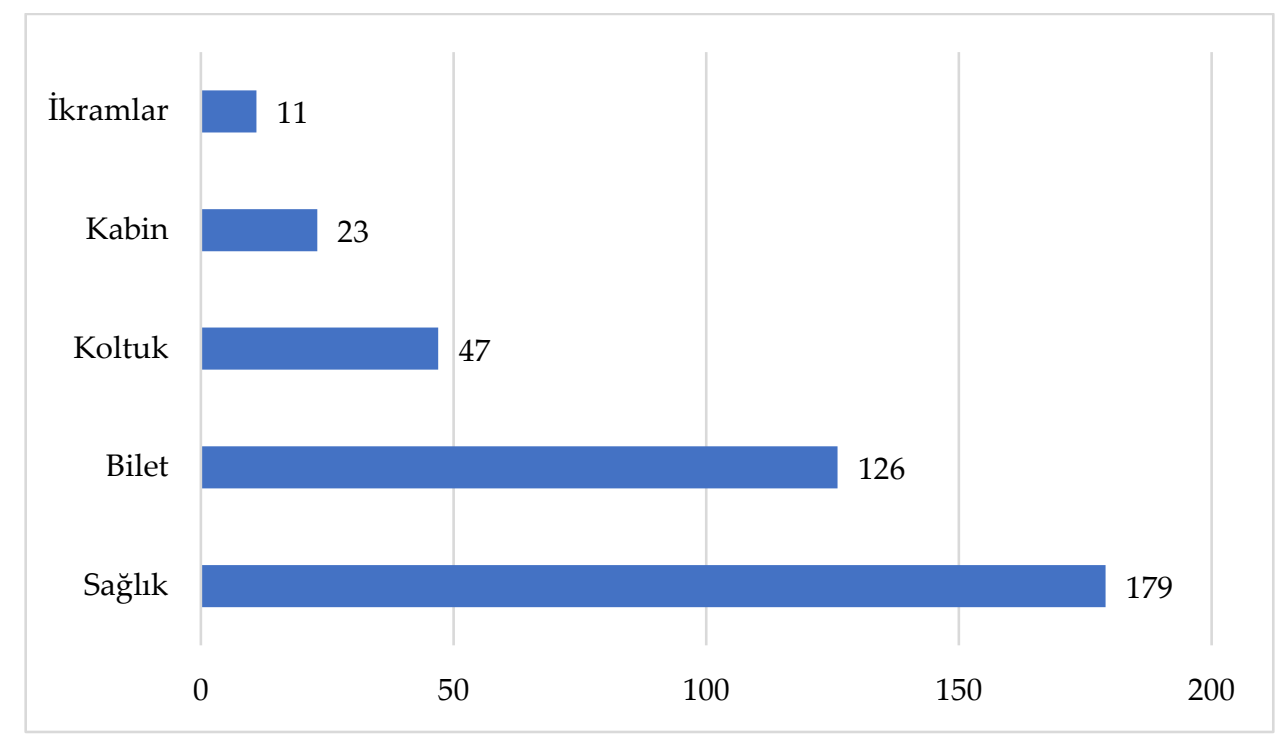

Grafik 1: Hava yolu Taşımacılığı Hizmetlerinde Önemli Olan Unsurlar

\subsection{Pandemi Sürecinde Yolcu Tutumlarına Etki Eden Beklentilerin/Tedbirlerin Tespitine İlişkin Bulgular}

"Covid-19 sürecinde havacılık sektöründe ne tür önlemlerin alınması sonucunda hava yolu taşımacılığını kullanmayı düşünürdünüz?" şeklinde katılımcılara yöneltilen soruya verilen yanıtlar doğrultusunda Grafik 2'deki gibi 11 ifade şeklinde genelleştirme yapılmıştır. Katılımcıların en çok tekrarladığ hijyenle ilgili tedbirlerin havada ve yerde sürekli uygulanması konusudur. Sosyal mesafeye, az yolcu ve boş koltuk uygulamasının tercihlerinde etkili ifadeleri ikinci sırada tekrarlanmıştır. Bundan sonraki ifadeler ise sırasıyla maske kullanımı, dezenfektanların her alanda bulunması, uçak ve havalimanında hava temizliğinin sürekli yapılması, ateş ölçümlerine dikkat edilmesi, eldiven kullanımı, kabin içinde yolcular arasında şeffaf bariyerlerin bulunması, Covid-19 hakkında yolculara havalimanında ve kabin içerisinde bilgilendirmelerin yapılması, kişisel koruyucu ekipmanların temin edilmesi ve son olarak kabin içerisinde ikram hizmetlerinin verilmemesi sayılmıştır. Sonuç olarak katılımcıların Covid-19'une etkisiyle sağlık ve hijyen faktörlerine dayalı tedbirlerin alınmasının katılımcılar için önemli olduğu anlaşılmaktadır.

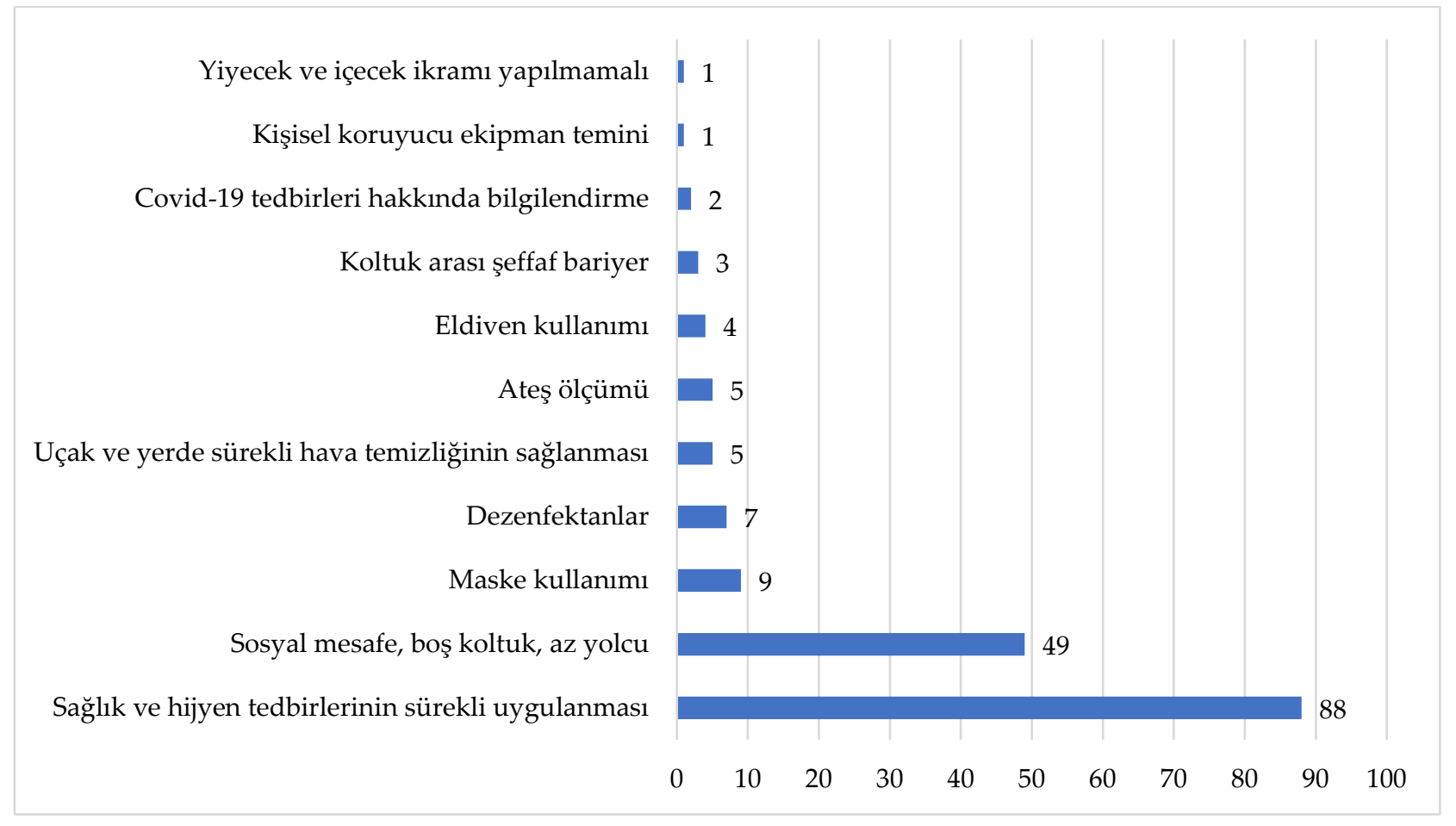

Grafik 2: Havacılık Sektöründe Alınması Gereken Önlemler 


\section{Sonuç ve Tartışma}

Covid 19'un etkisiyle birlikte tüm dünyada toplu taşıma araçlarında yolcu sayısının azaldığ insanların havacılık sektörüne olan tutumları, bu araştırmayla birlikte ortaya çıkarılmaya çalışılmıştır. Araştırma sonucunda ortaya çıkan pratik ve teorik katkılar şunlardır;

\section{Teorik Katkılar}

Bu çalışmada ölçek geliştirme ve sınama süreci olmak üzere üç adımdan oluşmaktadır. Illk adım olarak ölçek geliştirmek için nitel bir araştırma yapılmış, araştırmadan elde edilen ifadeler genelleştirilmiş ve son olarak uzman görüşü alınarak revizeye gidilmiştir. Revize sonrasında Covid-19 sürecinde hava yolu taşımacılığını kullanacak olan yolcuların beklentileri boyutu 12 madde ve bu süreçte gelişen tutumları boyutu 4 maddeden oluşmaktadır. Nitel çalışmaya dayalı olarak oluşturulan ölçeğin güvenduyulabilirliliği sağlanmıştır.

İkinci adımda ise başka bir örneklem grubuna Özkan (2020)'den alınan Covid-19 sürecinde korkuların oluşturduğu farkındalıklar boyutu için 4 madde ve nitel araştırmadan elde edilen beklenti ile tutumlar için 16 maddeden oluşturulan toplam 20 maddeli ölçek 322 katılımcıya uygulanmıştır. Ölçeği ilave olarak çalışmayı desteklemek amacıyla hava yolu taşımacılığında alınması gereken önlemler hakkında bir açı uçlu soru ve hava yolu taşımacılığında en önemli olan unsurlar için bir kapalı uçlu soru yöneltilmiştir. Geliştirilen ölçeğe uygulanan faktör analizi sonucunda korku üzerine olan maddelerden çıkarma yapılmaz iken tutumlar ve beklentiler boyutunda birer madde çıkarılmıştır. Ölçeğin geçerliliği ve güvenilirliği KMO testi, Barlett testi, Cronbach Alpha testiyle sağlandığı ve son olarak doğrulamak için DFA testi ile doğrulandığı tespit edilmiştir.

DFA testinden sonra kurulan hipotezlerin doğrulanması aşamasına geçilmiştir. Bunun için Yapısal Eşitlik Modeli kurulmuştur. YEM sonucunda oluşturulan hipotezlerin doğrulandığ görülmüş̧tür. Bunlar;

- Covid-19 sürecinde bağışıklık sisteminin güçlendirilmesinin, sağlıklı/doğal beslenmenin, sağlıklı yaşamanın ve hijyene dikkat etmenin ne kadar önemli olduğunun herkes tarafından fark edilmesi yani korkuların oluşturduğu farkındalıklar motivatörü ile yine bu süreçte oluşan beklentiler arasındaki ilişki ortaya çıkarılmıştır. Oluşturulan $\mathrm{H}_{1}$ hipotezinin gösterdiği bu sonuç Min vd. (2012)'nin yaptığı çalışmada, araştırma motivatörlerinin hizmet kalitesi beklentilerini artıracağ argümanına benzerdir. Bu bağlamda Covid-19 süreciyle birlikte tüketicilerin üzerinde oluşan korku verici uyarıcılar, tüketicileri havayollarından bu yönde beklenti içerisine sokmaktadır. Yazında duygusal motivatörleri üzerine yapılan birçok çalışmada korku verici somut/mantıklı uyarıcıların tüketiciler üzerinde beklentiler oluşturduğu sonucuna varılmaktadır (Elden, 2009; Odabaşı, 2010; Babür Tosun, 2010).

- Bu süreçte hava yolu taşımacıllğına karşı tutumlar ve beklentiler arasındaki ilişki ortaya çıkarılmış ve $\mathrm{H}_{2}$ hipotezi ile doğrulanmıştır. Bu durum Hsu vd. (2010) ile Ro ve Ha (2019)'un sonuçları ile benzerdir. Çalışmalarında tüketicilerin olumlu beklentisi tutumlarını olumlu etkilerken, tüketicilerin olumsuz beklentisi tutumlarını olumsuz etkilemektedir. Sonuç olarak tutumlar ve beklentiler arasında ilişki bulunmaktadır ve beklentiler tutumları etkilemektedir.

- Son olarak korkuların oluşturduğu farkındalıklar ile tutumlar arasındaki ilişki ortaya çıkarılmıştır. Papatya (2010)'a göre korku ya da benzer duygu motivatörleri, büyük bir endüstri olgusu haline dönüştürüldüğü zaman tüketici tutumları yönlendirilmekte ve yönetilebilmektedir. Bu savı ile $\mathrm{H}_{3}$ hipotezinde bulunan sonuç benzerdir. Yani şu an tüketiciler üzerinde oluşan Covid-19 pandemisinin korkuları tüketicilerin tutumlarına da yansımaktadır. Benzer şekilde Fishbein ve Ajzen (1975)'e göre tutumu uyandırmak veya değiştirmek için gerekli koşulların belirlenebildiğini ve bu tür koşulların tutumun motivasyonel temeline göre değişeceğini varsaymaktadır. Mevcut bir tutumun uyarılmasının temel koşullarından biri, bir bireyin ilgili ihtiyaç durumlarının etkinleştirilmesidir (Hsu vd., 2010). Bu bağlamda pazarlamacılar duygulardan hareket ederek tüketicilerin davranışlarını etkilemeye çalışmaktadırlar (Elden, 2009; Odabaşı ve Barış, 2010; Babür Tosun, 2010). Ayrıca bu durum Hsu vd. (2010)'nin sonuçları ile de benzerdir.

Bazı çalışmalarda hava yolu taşımacılığında alınacak önlemlerin neler olması gerektiğiyle ilgili araştırmaların yapıldığı görülmekle (Eroğlu, 2020) birlikte bu süreçte oluşan korkuların oluşturduğu farkındalıklar, beklentiler ve bunların tutumlarla olan ilişkisinin araştırılmadığı anlaşılmaktadır. Böylelikle bu çalışma ile bireylerin korkularının etkisiyle hava yolunu tercih etmelerini sağlayacak etmenlerin ortaya çıkarılmasına 
yönelik "Herhangi Bir Salgın Hastalık Durumunda Havacılık Sektöründe Tüketici Davranışları" üzerine bir ölçek kazandırılmaya çalışılmıştır. Ayrıca Covid-19 sürecinde oluşan korkuların, beklentilerin ve tutumların arasındaki etkileşim ile tüketici davranışları yazınına katkıda bulunulmaktadır.

\section{Pratik Katkılar}

Araştırmanın ikinci aşamasındaki katılımcılara yöneltilen açık uçlu soruyla hava yolunu kullanacak olan yolcuların havacılık sektöründen sağlık ve hijyen ile ilgili tedbirler konusunda beklentilerinin neler olduğu tespit edilmiştir. Hava yolu şirketlerinin tespit edilen bu hususlara Covid-19 süreci geçse bile dikkat etmeleri gerektiği sonucu ortaya çıkmaktadır.

Son olarak hava yolu ulaşımını tercih edecek yolucular için önemli olan unsurlar konusunda Diggines (2010), Dursun (2008), Cunningham vd. (2004), Farooq vd. (2018), Cheng ve Chang (2005), Aygün vd. (2017), Güngör vd. (2019)' un çalışmalarıyla paralel sonuçlar çıktığı görülmüştür. Bu çalışmalarda hava yolu ulaşımını kullanan yolcuların kabin memurlarının davranışları, temizlik, emniyetli uçuş, yer hizmetleri, zamanında inişkalkış, bilet fiyatının uygunluğu, fiziki ortamın kalitesi gibi unsurların hizmet kalitesinde önemli olduğu anlaşılmaktadır. Bu araştırmada ise APEX Yolcu Seçimi kriterlerine göre en önemli unsur sıralaması yapılmış ve sağlık/hijyenle ilgili tedbirlerin alınması birinci sırada çıkarken ikinci sırada bilet fiyatının uygunluğu çıkmıştır. Bu noktada Covid-19 sürecinin bir müddet daha devam edeceği düşünüldüğündü hava yolu şirketlerinin sağlı/hijyenle ilgili tedbirlere uyması gerektiği, ayrıca ülkemizin gelişmişlik ve gelir düzeyi göz önüne alındığında hava yolunu tercih edecek yolcuların fiyata duyarlı olduğunu göz önüne alarak tutundurma stratejilerini belirlemeleri gerekmektedir.

\section{Gelecek Araştırmalar için Öneriler}

Araştırma soruları bağlamında Covid-19 süreciyle birlikte insanların hangi şartlarda hava yolu taşımacılığını kullandıkları ve korkularının oluşturduğu farkındalıklar, beklenti ile tutumları arasındaki etkileşimi sunmakta ve yukarıda tartışıldığı gibi önemli sonuçlar sunmaktadır. Ancak çalışma Covid-19 sürecinin etkisiyle insanların araştırmalara katılma konusunda isteksiz olmaları gibi bazı kısıtlar altında yapılmıştır ve hazırlanan araştırma ölçeğinin gelecekte yapılacak araştırmalarla geliştirilmesine ve ilerletilmesine ihtiyaç olduğu açıktır. Bunun dışında şu noktalarda öneriler sıralanabilir:

İlk olarak, bundan sonra yapılacak araştırmalarda örneklem büyüklüğünün artırılması ve insanların tutumlarında değişiklik olup olmadığını anlamak için çalışmanın tekrarlanması önerilmektedir.

İkinci olarak, Covid-19 sürecinde oluşan korkuların bir psikolog desteğiyle duygusal boyutta ölçeklendirilerek hazırlanmasıdır. Yazın taramasında korku pazarlaması üzerine ölçek çalışmalarının nitel boyutta kaldığı tespit edilmiştir. Ölçek geliştirmek için Papatya (2010)'un seminal makalesinde ele aldığı gibi sağlık, güvenlik, güzellik ve diğer birçok farklı alanlarda da konunun ela alınması ya da tüm sektörleri içine alabilecek korkuların genellenebildiği ve korkuların tüketici davranışlarına etkisinin incelendiği bir ölçek geliştirme sonrası çalışmalar için yapılabilir.

Son olarak, korku pazarlaması üzerine araştırmaların az sayıda olmasından dolayı gelecekte konunun farklı coğrafi ölçeklerde ve sektörlerde araştırılması ve buna bağlı karşılaştırmalar yapılmasının ihtiyaç olduğu ifade edilebilir. 


\section{KAYNAKÇA}

Addo, P. C., Jiaming, F., Kulbo, N. B. and Liangqiang, L. (2020) Covid-19: fear appeal favoring purchase behavior towards personal protective equipment, The Service Industries Journal, 40(7-8), 471-490.

Akça, Ö.Ü.M. (2020). Covid-19'un havacılık sektörüne etkisi, Avrasya Sosyal ve Ekonomi Araştırmaları Dergisi, 7(5), 45-64.

Akyüz, A. M., Ayyıldız, H. ve Yetim, F. (2017). Olumsuz değerlendirilme korkusu ile ani-kompulsif satın alma davranışı ilişkisinde yatay bireysellik ve/veya normatif uyumluluğun olası etkilerinin incelenmesi, Karadeniz Teknik Üniversitesi Sosyal Bilimler Enstitüsü Sosyal Bilimler Dergisi, 7(14), 261274.

Arastaman, G., Öztürk Fïdan, İ. ve Fïdan, T. (2018). Nitel araştırmada geçerlik ve güvenirlik: kuramsal bir inceleme, Yüzüncü Yıl Üniversitesi Ĕ̆itim Fakültesi Dergisi, 15 (1), 37-75.

Avcı, M . (2017). Güvenliğin pazarlanması: bir pazarlama aracı olarak suç ve şiddet, Balkan Sosyal Bilimler Dergisi , (ICOMEP 2017 Özel Sayıs1) , 9-16.

Aygün, D., Yılmaz, İ. G. and Gülseçen, S. (2017). The value of decision making to the airlines: An analysis of passenger preferences on check-ins, Journal of Transportation and Logistics, 2(1), 1-10.

Babür Tosun, N. (2010). İletişim Temelli Marka Yönetimi, İstanbul, Beta Yayım.

Balcı, Ş. (2006). Negatif Siyasal Reklamlarda İkna Edici Mesaj Stratejisi Olarak Korku Çekiciliği Kullanımı, (Yayınlanmamış Doktora Tezi), Selçuk Üniversitesi, Sosyal Bilimler Enstitüsü, Konya. Yükseköğretim Kurulu Tez Merkezi'nden edinilmiştir. (Tez No. 189311).

Beck, M. J. and Hensher, D. A. (2020). Insights into the impact of covid-19 on household travel and activities in Australia-the early days under restrictions, Transport Policy, 96, 76-93.

Büyüköztürk, Ş. (2009). Sosyal Bilimler İçin Veri Analizi El Kitabı (10. Baskı), Ankara: Pegem Akademi.

Chen, F. and Chang, Y. (2005). Examining airline service quality from a process perspective, Journal of Air Transport Management, 11(2), 79-87.

Cotfas, L. A., Delcea, C., Milne, R. J., and Salari, M. (2020). Evaluating classical airplane boarding methods considering covid-19 flying restrictions, Symmetry, 12(7), 1087.

Cunningham, F. L., Young, E. C. and Lee, M. (2004). Perceptions of airline service quality, pre and post 9/11, Public Works Management and Policy, 9(1), 10-25.

Çakar, S. (2009). Reklamlarda Korku Çekiciliğinin Kullanılması (Yayınlanmamş Yüksek Lisans Tezi). Bahçeşehir Üniversitesi, Sosyal Bilimler Enstitisü, İstanbul. Yükseköğretim Kurulu Tez Merkezi'nden edinilmiştir. (Tez No. 263351).

Çakı, C. (2018). Birinci Dünya Savaşı'nda propaganda amaçlı kullanılan posterlerin korku çekiciliği bağlamında incelenmesi: Büyük Britanya örneği, Atatürk Illetişim Dergisi, 15, 111-136.

Çalışkan, A. (2020). Kriz yönetimi: bir ölçek geliştirme çalışması, Türk Sosyal Bilimler Araştırmaları Dergisi, $5(2), 108-123$.

Çapık, C. (2014). Geçerlik ve güvenirlik çalışmalarında doğrulayıcı faktör analizinin kullanımı, Journal of Anatolia Nursing and Health Sciences, 17(3), 196-205.

Çevik, E. M. (2011). Gıda ürünlerinde kullanılan tutundurma yöntemleri ve reklamın etkisi (Yayınlanmamış Yüksek Lisans Tezi). Namık Kemal Üniversitesi, Fen Bilimleri Enstitütüsü, Tekirdağ. Yükseköğretim Kurulu Tez Merkezi'nden edinilmiştir. (Tez No. 300265)

De Haas, M., Faber, R., and Hamersma, M. (2020). How Covid-19 and the Dutch 'intelligent lockdown'change activities, work and travel behaviour: Evidence from longitudinal data in the Netherlands, Transportation Research Interdisciplinary Perspectives, 100150, 1-11.

De Meyer, A. (2020). It won't be business as usual after Covid-19, Straits Times, A18-A18. Research Collection Lee Kong Chian School Of Business. Available at: https://ink.library.smu.edu.sg/lkcsb_research/6558.

Depoux, A., Martin, S., Karafillakis, E., Preet, R., Wilder-Smith, A., and Larson, H. (2020). The pandemic of social media panic travels faster than the Covid-19 outbreak, Journal of Travel Medicine, 27(3), 12. 
Derendeli, T. (2019). Reklamlarda Korkunun Bir Pazarlama Aracı Olarak Kullanılması: Korku Mesajı Içeren Reklamların Göstergebilimsel Çözümleme Tekniğgiyle İncelenmesi (Yayınlanmamış Yüksek Lisans Tezi). Karabük Üniversitesi, Lisansüstü Eğitim Enstitüsü, Karabük. Yükseköğretim Kurulu Tez Merkezi'nden edinilmiştir. (Tez No. 602981).

Diggines, S. (2010). Passenger perceptions and understanding of the low-cost and full service airline models in South Africa and the implications for service strategy, International Research Symposium in Service Management, 24(27).

Dursun, M.E. (2008). Havayolu İşletmelerinde Uçuş Öncesi, Uçuş Esnası Ve Uçuş Sonrasında Sunulan Hizmetlerin Kalitesinin Ölçülmesi: İç Hatlarda Bir Uygulama (Yayınlanmamış Yüksek Lisans Tezi), Anadolu Üniversitesi, Sosyal Bilimler Enstitüsü, Sivil Havacılık Yönetimi Ana Bilim Dalı Eskişehir. Yükseköğretim Kurulu Tez Merkezi'nden edinilmiştir. (Tez No. 234365)

Elden, M. (2009). Reklam ve Reklamcılık, İstanbul, Say Yayınları.

Eroğlu, Y. (2020). Küresel pandemi öncesi hava yolu şirketlerinde yolcu tutumlarına etki eden unsurların tespit edilmesine yönelik bir değerlendirme, Journal of Hospitality and Tourism Issues, 2(1), 25-38.

Erol, E. G. (2017). Tv Reklamlarında korku çekiciliği olgusu: 2010-2017 yılları arası tv reklamlarına yönelik bir araştırma, INIF E-Dergi, 2(2), 55-67.

Farooq, M. S., Salam, M., Alain Fayolle, N. J. and Ayupp, K. (2018). Impact of service quality on costumer satisfaction in Malaysia Airlines: A PLS-SEM approach, Journal of Air Transport Managemet, 67, 169180.

Fırat, D. (2013). Korkunun bir pazarlama aracı olarak uygulanması: işletmelerin korku mesajları ile tüketicilerin algısı arasında uyum var mı?, Sosyal ve Beşeri Bilimler Dergisi, 5(1), 187-197.

Fırat, D. ve Yıldız, Y. G. (2019). Reklamlarda kullanılan korku öğesine karşı tüketicilerin sergilemiş olduğu tutumlar, Gümüshane Üniversitesi Sosyal Bilimler Enstitüsü Elektronik Dergisi, 10(1).

Gerçek, M . (2018). Yöneticiler için psikolojik sözleşme ölçeği: bir ölçek geliştirme, geçerlilik ve güvenilirlik çalışması, Anadolu Üniversitesi Sosyal Bilimler Dergisi , 18 (4) , 193-212

Graham, A., Kremarik, F., and Kruse, W. (2020). Attitudes Of Ageing Passengers To Air Travel Since The Coronavirus Pandemic, Journal of Air Transport Management, 101865.

Güngör, O., Güngör, M. Y. and Doğan, S. (2019). Examining the evaluations in TripAdvisor about Turkish Airlines, Journal of Tourism Theory and Research, 5(2), 282-291.

Gürdin, B. (2016). Sigara karşıtı televizyon reklamlarında kullanılan korku çekiciliği faktörü etkinliğinin beyin görüntüleme tekniği ile ölçümü (Yayınlanmamış Doktora Tezi), Adnan Menderes Üniversitesi, Sosyal Bilimler Enstitüsü, Aydın. Yükseköğretim Kurulu Tez Merkezi'nden edinilmiştir. (Tez No. 446319).

Hsu, C. H., Cai, L. A. and Li, M. (2010). Expectation, motivation, and attitude: A tourist behavioral model. Journal of Travel Research, 49(3), 282-296.

http 1- BBC News. (2020). Koronavirüs salgını: Uçaklardaki yeni düzenlemeler neler, havayolu şirketleri hangi önlemleri alıyor?, https://www.bbc.com/turkce/haberler-dunya-52814311 (Erişim Tarihi: 18 Temmuz 2020).

http 2- THY. (2020). Güvenli seyahat standartlarımız, https://www.turkishairlines.com/tr-int/guvenliseyahat-standartlarimiz/ (Erişim Tarihi: 18 Temmuz 2020).

http 3- Pegasus. (2020). Sağlıklı uçuşlar için önlemlerimiz, https://www.flypgs.com/koronavirusonlemleri-ve-dezenfeksiyon-proseduru (Erişim Tarihi: 18 Temmuz 2020).

Ivanova, M., Ivanov, I. K., and Ivanov, S. (2020). Travel behaviour after the pandemic: the case of Bulgaria, Anatolia, 1-11.

İslamoğlu, G., ve Börü, D. (2007). Politik davranış boyutları: bir ölçek geliştirme çalışması, Akdeniz Üniversitesi Iktisadi ve İdari Bilimler Fakültesi Dergisi, 7(14), 135-153.

Kalaycı, Ş. (2008). SPSS Uygulamalı Çok Değişkenli İstatistik Teknikleri (3. Baskı), Ankara, Asil Yayıncılık.

Khine, M. S. (2013). Application Of Structural Equation Modeling İn Educational Research And Practice, Netherlands, Sense Publishers. 
Kılıç, H. Ö. ve Derendeli, T. (2020). Reklamlarda korkunun bir pazarlama aracı olarak kullanılması, Business \& Management Studies: An International Journal, 8(2), 1221-1254.

Korkmaz, İ. ve Dal, N.E. (2020). Korku pazarlaması içinde, İktisadi ve idari bilimlerde teori ve araştırmalar II, Ed. M. Mete, Ankara, Gece Kitaplığı.

Kurtuluş, K. (2006). Pazarlama Araştırmaları, İstanbul, Literatür Yayıncılık.

Macit, A. ve Macit, D. (2020). Türk sivil havacıllk sektöründe covid-19 pandemisinin yönetimi, Avrasya Sosyal ve Ekonomi Araştırmaları Dergisi, 7(4), 100-116.

Min, S., Khoon, C. C., and Tan, B. L. (2012). Motives, expectations, perceptions and satisfaction of international students pursuing private higher education in Singapore, International Journal of Marketing Studies, 4(6), 122.

Odabaşı, Y. ve Barış, G. (2010). Tüketici davranışları, İstanbul, MediaCat.

Özer, E. Z. ve Aksoy, M. (2018). Korku çekiciliğinin gıda korkusu üzerine etkisi (the impact of fear appeals on the fear of food), Journal of Tourism and Gastronomy Studies, 6 (3), 359-369.

Özkan, T. (2020). Covid-19 Sürecinde Tüketici Davranışları, Karışmaz, E. (Ed.), Covid-19 Sürecinin Ekonomik Ve Sektörel Etkileri, Ankara, IKSAD Publishing House, 285-299.

Papatya, N. (2010). Korku pazarlaması: ironik ve eleştirel bir katkı, PI Dergisi, 9(31), 1-17.

Parasuraman A., Zeithaml V. A. and Berry L. L. (1985). A conceptual model of service quality and its implications for future research, Journal of Marketing, 49, Fall, 41-50.

Ro, Y. and Ha, Y. (2019). A factor analysis of consumer expectations for autonomous cars, Journal of Computer Information Systems, 59(1), 52-60.

Sariyer, N. (2019). Effect of fear on purchasing sensitivity-a netnographic study in 4 th International Symposium on Innovative Approaches in Social, Human and Administrative Sciences, Samsun, Turkey, 22-24 November 2019, Turkey, 271-276.

Savaş, H. ve Kesmez, A. G. (2014). Hizmet kalitesinin servqual modeli ile ölçülmesi: aile sağllğı merkezleri üzerine bir araştırma, Pamukkale Üniversitesi Sosyal Bilimler Enstitüsü Dergisi, (17), 1-13.

Schermelleh-Engel, K. and Moosbrugger, H. (2003). Evaluating the fit of structural equation models: tests of significance and descriptive goodness-of-fit measures, Methods of Psychological Research Online, $8(2), 23-74$.

Schumacker, R. E. and G. Lomax, R. (2010), A beginner's guide to structural equation modeling, Third Edition, New York London, Routledge.

Seçer, İ. (2015). SPSS ve LISREL İle Pratik Veri Analizi, Ankara, Anı Yayıncılık.

Seki, Ö. (2017). İkna edici ıletişim açısından korku çekiciliği kullanımı: Sağlık Bakanlığı tarafından yayınlanan kamu spotları örneği (Yayınlanmamış Doktora Tezi), Selçuk Üniversitesi, Sosyal Bilimler Enstitüsü, Halkla İlişkiler ve Tanıtım Ana Bilim Dalı, Konya. Yükseköğretim Kurulu Tez Merkezi'nden edinilmiştir. (Tez No. 471191).

Şentürk, T. (2020). Sosyal pazarlamada hakkında teori ve modeller, Selçuk Üniversitesi Sosyal Bilimler Meslek Yüksekokulu Dergisi, 23 (2), 603-621.

Yiğit, S. (2018). Etnik mutfak ürünlerinin tercihinde neofobinin etkisi: karşılaştırmalı bir uygulama (Yayınlanmamış Yüksek Lisans Tezi), Balıkesir Üniversitesi, Sosyal Bilimler Enstitüsü, Balıkesir. Yükseköğretim Kurulu Tez Merkezi'nden edinilmiştir. (Tez No. 511709). 